IRA-International Journal of Management \& Social Sciences

ISSN 2455-2267; Vol.07, Issue 01 (2017)

Pg. no. 20-32

Institute of Research Advances

https://research-advances.org/index.php/RAJMSS

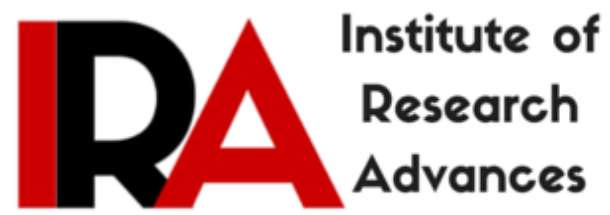

\title{
Impact of Information and Communication Technology on Service Quality of Banking Sector: A Comparative Study of Private and Public Sector Banks in Gwalior and Chambal Region
}

Prof (Dr.) Anil Vashisht

Director, Amity Business School, Amity University Madhya Pradesh, India.

Type of Review: Peer Reviewed.

DOI: http://dx.doi.org/10.21013/jmss.v7.n1.p3

\section{How to cite this paper:}

Vashisht, A. (2017). Impact of Information and Communication Technology on Service Quality of Banking Sector: A Comparative Study of Private and Public Sector Banks in Gwalior and Chambal Region. IRA-International Journal of Management \& Social Sciences (ISSN 2455-2267), 7(1), 20-32. doi:http://dx.doi.org/10.21013/jmss.v7.n1.p3

(C) Institute of Research Advances

\section{$(\mathrm{cc})$ BY-NC}

This work is licensed under a Creative Commons Attribution-Non Commercial 4.0 International License subject to proper citation to the publication source of the work.

Disclaimer: The scholarly papers as reviewed and published by the Institute of Research Advances (IRA) are the views and opinions of their respective authors and are not the views or opinions of the IRA. The IRA disclaims of any harm or loss caused due to the published content to any party. 


\section{ABSTRACT}

This paper studies the impact of IT in the service quality of banking sector. The purpose of the intended research involves determining bank adoption pattern of electronic media, factors constituting drivers and inhibitors for bank adoption, dimensionality of e-banking services quality as affected by IT, and customer adoption of such services. The study has also highlighted the determinants of service quality are directly influenced by IT and to explore what are the enabling and retarding factors for effective implementation and upsurge of IT system in banks.

\section{Introduction}

A Strong Information Technology (IT) base has emerged as a key precondition for any developing country's improved competition and financial and societal modernization. Electronic services which are driven by IT technologies, have recently received extensive consideration as these are situated at the intersection of two noteworthy improvements in the business world: the service growth and ICT (Information and Communication Technology) entrance (Fassnacht \& Koese, 2006). In India, the adoption of IT is picking up momentum upheld by booming service sector (64\% of GDP in 2015-16) and growing telecom division (the second biggest telecom market by subscriber base, 2016). IT is ruling in the new service improvement and delivery channels especially on the grounds that the requirement for intelligence and data force (Corrocher, 2002) has been brought significantly up in the changing spaces of organizations today. The appearance and selection of IT combined with communication system by commercial enterprises has expelled the constraints of time, distance, and communication(Khan et al., 2009) making the economy more networked and knowledge driven.

IT in banks is promising and additionally lucrative as far as operational and vital advantages it offers. IT gives advantages to the banking organisations as far as decreased operational cost, better client administration and improvement of sophisticated product offerings as it encourages better "Asset liability management" and propelled statistical surveying (Phillips et al., 1983; Zeithaml et al., 1988; Allred and Addams, 2000; and Buzzell, 2004). In the Indian banks perspective, all banks have consolidated IT in their techniques and operations however at various levels relying on the main driving forces and obstructions for its effective execution.

Tools and technologies are deployed by service organizations to fill the quality gaps that may arise during service delivery. IT is one of these technologies that fills the information gap and automates the services to enhance its speed and accuracy thereby enhancing the service quality. IT innovations in processes or service delivery have positive impact on product output and quality (Mukhopadhyay et al., 1997). E-Banking offers more value to the customers as far as information, serviceability, comfort, more extensive collection of offerings, and much more. Attitude of bank customer plays a vital role in adoption and propagation of innovative e-Banking services in banking sector. Besides success of innovation in banking services also depend upon the "perception and consumption patterns" of its users. Customers adopt innovative services easily if these are perceived to be high quality. Besides, high service quality increases customer satisfaction and loyalty.

Direct relation has been found between improved service quality and intention to purchase (determining service usage) (Zeithaml et al., 1996). However, pursuing and maintaining the highest level of service quality often costs too much at the front level (Nam et al., 2006). The critical decision for the firm is to determine and maintain desired rather optimal level of service quality. So the purpose of the this research involves determining bank adoption pattern of electronic media, factors constituting drivers and inhibitors for bank adoption, dimensionality of e-banking services quality as affected by IT, and customer adoption of such services.

The review of existing literature also reveals that very little work has been done in relation to adoption of Information Technology (IT) in the Indian banking sector at regional level. The intention behind this research, therefore, is to fill this gap by exploring thoroughly and comprehensively this field of research. Moreover, there is very little work existing on the relationship between IT and banking services quality as far as India is concerned. 
Given the lack of literature and knowledge on this subject, it is a modest attempt to examine how information technology and services quality interrelate in the banking context as perceived by the bank customers and the likely impact of such quality perceptions on the usage or adoption of new technologies. The study would also highlight which determinants of service quality are directly influenced by IT and to explore what are the enabling and retarding factors for effective implementation and upsurge of IT system in banks.

\section{Literature review}

Many studies have been conducted both at national and international level to evaluate the adoption of Information and communication technologies (ICT). Generally the researcher concentrated on examining the elements influencing firm's choice to embrace new technologies. Studies related to banking sector reported organizational, technological, environmental (competitive, regulatory, market oriented) as major affecting components for IT adoption.

Relationship between firm's decision to adopt new technologies and its determinants was examined and found that the product mix of banks was positively associated with the technology adoption. Wage rate showed significant positive relation with adoption while market growth rate showed no significant impact on adoption of new technologies. The bank's regulatory environment also found to affect the decisions of adopting new technologies (Hannan \& McDowell, 1984). Adoption of new technology, like video banking by US commercial banking was explored and revealed that IT and inter-firm linkages increases the tendency of commercial banks to do the innovation and keeping other attributes related to company and industry under control. The study found no association between tendency to innovate and productivity index and technological investment (Pennings \& Harianto, 1992). Innovation patterns arise from the dispersion of IT in banking sector of Italy have been studied and results revealed that there is no significant association exist for technological and competitive factors with e-Banking adoption (Bradley \& Stewart, 2002). Study in India has been conducted to asses the drivers of IT enabled banking (ITEB) in India and to know the current status of ITEB. The study concluded that private sector banks are way ahead of public sector bank in adoption of IT enabled technologies (Kumra \& Mittal, 2004).

Key drivers to enhance the soundness of banking industry have been studied in developed and developing countries and it has been found that ICT infrastructure, intellectual capital have postive but non-significant effect on the soundness of banking sector while strategic partnership, governance have positive significant effect and interaction have negative significant effect on bank soundness (Vaithilingam, Nair, \& Samudram, 2006). 88 scheduled commercial banks in India has been studied to examine the factors affecting the bank's decision to adopt e-Banking. The factors found are biggersize, younger-age, large-deposit-base, low-market-share of banks have postive significant affect on eBanking adoption by banks(Malhotra \& Singh, 2007). It has been found that bank staff resistance to adopt IT technology is the biggest reason for slow growth e-Banking technology in Lybia (Abukhzam \& Lee, 2010).

Major drivers for adoption of online banking services were identified as customer-oriented and market-oriented factos. Support by top management, lack of internet-specialists, change in IT technologies are some concerns for the management for system development (Aladwani, 2001). The tendency to adopt e-Banking is affected by the size of the firm, branch intensity, sophistication of users, income and education(Corrocher, 2006). Factors like customer's passivity, technicalcomplexities, less security, intensity of branch, absense of support by top management, attitude of customers etc have affected the adoption of Internet banking at bank level(Bradley \& Stewart, 2002; Abukhzam \& Lee, 2010). A large portion of the studies have taken adoption as "binary variable (adopted or not adopted)".

Different Theories have been proposed towards understanding real customer behavior. Particularly, Theory of Reasoned Action (Fishbein and Ajzen's ,1975), Social cognitive theory (Bandura, 1982), Diffusion of innovations theory (Rogers, 2003), Technology Acceptance Model (Davis, 1989), Theory of Planned Behaviour (Ajzen, 1991), Task- Technology Fit theory (Goodhue and Thompson, 1995), the Unified theory of acceptance and use of technology (Venkatesh et al., 2003), advanced different elements deciding the perceptions, beliefs, and attitudes of actual users contributing 
knowledge into comprehension the level of appropriation of e-Banking. Different endeavours have been made to develop these theories joining new factors or applying distinctive hierarchical setups.

Aside from applying and amplifying prevalent theories of acceptance of technplogy, the center of a great part of the examination is laid on instrumentality of technology acknowledgment considering different variables like demographics, trust, past experience, information content, self interest, social influence, and other consumer traits (Venkatesh and Morris, 2000; Mansor and Mat, 2009; Margaret and Ngoma, 2013). In the Indian context, there are just few studies concentrated on IT adoption (Agarwal and Prasad, 1999; and Agarwal and Karahanna, 2000) and specially in banking sector (Gupta, 2008; Joshua and Koshi, 2009; Sharma, 2011; and Kesharwani and Bisht, 2012).

Numerous analysts sought solid and direct connection between perceived service quality and customer satisfaction (Naik et al., 2010) also, it has been demonstrated that service quality influences satisfaction and that satisfaction thusly influences behavioral expectations (Ruyter et al., 1997; Wang and Sheikh, 2006). There is by all accounts a lot of closeness between these two ideas, yet a few researcher precisely expressed that these are two unique develops (Spreng and Mackoy, 1996) Satisfaction is transaction particular while quality can be seen without genuine utilization experience (Oliver, 1989).

Strong relationship found between IT adoption and improvement of service quality (Wong et al., 2008). Major framework used in evaluation of service quality are SERVQUAL (Parasuraman, 1988) and SERPERF (Cronin and Taylor, 1992). Different models have been suggested for website service quality (Parasuraman et al., 2005; Bauer et al., 2006). Some noticeable work has been done to evaluate the service quality in banking sector (Avkiran, 1999; Sohail and Shaikh, 2008; Ariff et al., 2012). In India's context the literature has limited work related to evaluation of service quality in banking sector (Sureshchandar et al., 2002; Sudhahar et al., 2006; Purohit and Patardikar, 2007; and Arora et al., 2011) and e-banking service quality evaluation in particular (Khan et al., 2009). Overall service quality was measured using three items on 5 point likert scale (with endpoints strongly agree/strongly disagree) referred to 'Excellent overall service', 'Service of a very high quality', 'A high standard of service', (Dabholkar, 1995; Spreng and Mackoy, 1996; and Dabholkar et al., 2000)

\section{Objectives of the study}

1. To determine the leading technologically influenced factors of service quality in banking sector.

2. To examine the impact of identified technologically influenced factors on overall service quality in banking sector.

\section{Scope of the study}

Information technology proved to be beneficial for service sector to improve efficiency and effectiveness of services offered to the customers. In case of Indian banking sector, almost all the banks have adopted the IT in their working but at different level depends upon the drivers and impediments of its successful implementation. Direct association found between high service quality and customers intention to purchase the product/services (Zeithaml et al., 1996). This study will be helpful to the banking sector to identify the technology driven factors of service quality in banking sector which will be useful for banks to improve their service quality. This study will also be helpful to identify different factors influence customers to adopt e-Banking services.

\section{Research Methodology}

5.1 Universe of the study: The universe of the study consists of banking community of Gwalior and Chambal region.

5.2 Sampling Frame: This carried out among the customers of banks in Gwalior and Chambal region.

5.3 Sampling Size: For this study a sample of 5 public and 5 private scheduled commercial banks will be taken from each selected city of Gwalior and Chambal region. The banks are selected on the 
basis of market capitalization in India. A sample size of 300 customers has been selected from the selected cities.

Table 5.1: Top 5 public sector commercial Banks on the Basis of market capitalization

\begin{tabular}{|l|l|l|}
\hline Sr. No & Name of bank & Market capitalization ( In Rs. Crore) \\
\hline 1 & State Bank Of India & $176,447.92$ \\
\hline 2. & Bank Of Baroda & $34,344.84$ \\
\hline 3. & Punjab National Bank & $23,847.89$ \\
\hline 4. & Central Bank Of India & $17,057.4$ \\
\hline 5. & IDBI Bank & 14,082 \\
\hline
\end{tabular}

Source: BSE website 2016

Table 5.2: Top 5 private sector commercial Banks on the Basis of market capitalization

\begin{tabular}{|l|l|l|}
\hline Sr. No & Name of bank & Market capitalization ( In Rs. Crore) \\
\hline 1 & HDFC Bank & 314,764 \\
\hline 2. & ICICI Bank & 144,962 \\
\hline 3. & Kotak Mahindra Bank & $138,427.15$ \\
\hline 4. & Axis Bank & $131,367.39$ \\
\hline 5. & Indusland Bank & $71,352.18$ \\
\hline
\end{tabular}

Source: BSE website 2016

5.5 Sampling Method: Non-Probabilistic Judgemental Sampling

5.6 Data Collection: For this study, both primary and secondary data has been used. The secondary data has been collected from the available literature, RBI websites and other sources whereas primary data has been collected from the selected respondent directly by using comprehensive questionnaire for customers.

\section{Data Analysis and interpretations}

19 factors have been identified by carrying a vast literature review objective of finding out a comprehensive set of variables or items indicating the service quality of banking services influenced by infusion of technology specifically IT. The variables had been majorly derived from the earlier studies conducted both in India and abroad in varied fields

Table 6.1: List of factors relevant for e-Service Quality

\begin{tabular}{|l|l|}
\hline Sr no & Item/Variable \\
\hline 1 & Ensure Security \\
\hline 2 & Effective grievance handling \\
\hline 3 & Increased comfort \\
\hline 4 & Easy accessibility \\
\hline 5 & Reduced cost \\
\hline 6 & Easy availability \\
\hline 7 & Quick response \\
\hline 8 & Seamless Transactions \\
\hline 9 & Willingness of employees to service customers \\
\hline 10 & Fast transactions \\
\hline 11 & Ensured safety \\
\hline
\end{tabular}




\begin{tabular}{|l|l|}
\hline 12 & Visually appealing material \\
\hline 13 & Attractive screen layout and design \\
\hline 14 & Service right the first time \\
\hline 15 & Transaction within committed time \\
\hline 16 & Employees find time to respond customers \\
\hline 17 & Knowledgeable employees \\
\hline 18 & Instill confidence in customers \\
\hline 19 & Individual attention to customers \\
\hline
\end{tabular}

The opinions of customers regarding impact of technology on different variables reflecting quality of service were measured on a five point likert scale from 5 to 1 depending upon the agreeability on each variable ( 5 for strongly agree followed by 4 for agree, 3 for neutral, 2 for disagree, and 1 for strongly disagree). All variables were coded likewise.

In order to find out the extent of technological influence on each variable, the variable wise average scores have been analysed. This analysis is based upon the customers' perceptions about different variables.

Table 6.2: Descriptive Statistics - Variables relevant for e-service quality

\begin{tabular}{|l|l|l|l|}
\hline & & Average scores & Std. Deviation \\
\hline A4 & Easy accessibility & 4.32 & 0.587 \\
\hline A3 & Increased comfort & 4.39 & 0.658 \\
\hline A6 & Easy Availability & 4.3 & 0.585 \\
\hline A10 & Fast transactions & 4.3 & 0.633 \\
\hline A7 & Quick response & 4.33 & 0.69 \\
\hline A5 & Reduced cost & 4 & 0.834 \\
\hline A18 & Instill confidence in customers & 3.9 & 0.671 \\
\hline A15 & $\begin{array}{l}\text { Transaction within committed } \\
\text { time }\end{array}$ & 3.78 & 0.728 \\
\hline A14 & Service right the first time & 3.66 & 0.754 \\
\hline A13 & $\begin{array}{l}\text { Attractive screen layout and } \\
\text { design }\end{array}$ & 3.66 & 0.636 \\
\hline A17 & Knowledgeable employees & 3.74 & 0.743 \\
\hline A8 & Seamless transactions & 3.74 & 0.835 \\
\hline A12 & Visually appealing material & 3.73 & 0.617 \\
\hline A19 & $\begin{array}{l}\text { Individual attention } \\
\text { customers }\end{array}$ & 3.71 & 0.769 \\
\hline A2 & Effective grievance handling & 3.68 & 0.829 \\
\hline A1 & Ensure security & 3.68 & 1.028 \\
\hline A16 & $\begin{array}{l}\text { Employees Find time to } \\
\text { respond customers }\end{array}$ & 3.66 & 0.817 \\
\hline A9 & $\begin{array}{l}\text { Willingness of employee to } \\
\text { service customers }\end{array}$ & 3.66 & 0.738 \\
\hline A11 & Ensured safety/confidentiality & 3.64 & 0.805 \\
\hline & Cronbach's Alpha = 0.878 & & \\
\hline & & & \\
\hline
\end{tabular}




\begin{tabular}{|l|l|}
\hline Average Score & Significance level \\
\hline $4.00-5.00$ & Highest \\
\hline $3.00-3.99$ & Moderate \\
\hline $2.00-2.99$ & Slight \\
\hline $1.00-1.99$ & Lowest \\
\hline
\end{tabular}

Descriptive Table 6.2 shows the average scores for each item. The highest score has been given to the item 'Easy accessibility' to the service and the lowest score was recorded for the item 'Ensure confidentiality'. This shows that the most technological influenced parameters in banking are accessibility to the service, availability of service, comfort for customers, promptness of service and information delivery (with average score $>=$ ' 4 '). All other factors are moderately influenced by IT in banking with average scores less that ' 4 ' but more than ' 3 '.

6.1 Factor Analysis for determining technologically influenced determinants of service quality

To better understand the construct of variables, factor analytical technique has been applied in order to summarize the items into meaningful groups. Factor analysis has been employed to determine patterns of interrelationships among variables relevant for service quality that are influenced by IT inclusion in banking. To test reliability of data, Cronbach's alpha statistic has been calculated. For the set of 19 variables, the value of Cronbach's alpha is 0.878 which is greater than 0.5 hence, satisfies the condition for the reliability of the sample data for further analysis.

Kaiser-Meyer-Olkin (KMO) Measure of Sampling Adequacy was found to be $0.860(\mathrm{p}=0.00)$ (refer Table 6.5) showing high adequacy and considered as 'meritorious' as given by Kaiser, 1974. KMO statistic for individual variables was also checked from Anti-Image correlation matrix by examining the diagonal elements, which was above 0.5 for each variable, hence acceptable.

Bartlett test of Sphericity indicated test value $\chi^{2}=399.8$ which is highly significant ( $\mathrm{p}=0.0001$ ) (refer Table 6.3).

Table: 6.3 KMO and Bartlett's Test for variables relevant for e-Service Quality

\begin{tabular}{|l|l|}
\hline Kaiser-Meyer-Olkin Measure of Sampling Adequacy. & 0.86 \\
\hline Bartlett's Test of Sphericity & \\
Approx. Chi-Square & \\
Sig. & 399.879 \\
\hline
\end{tabular}

Principal component analysis was applied to extract factors and six factors were retained based on the Eigen values (more than 1) and variances explained by each factor. The initial factor solution (unrotated factor solution) extracts factors in the order of their importance. As we can see in Table 6.6 , factor 1 is accounting for largest portion of the variance in the data $(28.92 \%)$ with remaining each accounting for successively smaller portions of variance. To redistribute the variance from earlier factors to later ones and to make the factor solution more meaningful, rotation of factors was applied. This is an important tool in interpreting factors wherein the axes of the factors are rotated until some other more desirable position has been reached. The factors can be rotated using either orthogonal (the axes are maintained at $90^{\circ}$ ) or oblique (rotated otherwise) rotation. The most popular algorithm for orthogonal rotation is VARIMAX that was also employed for the current study. The results of the rotation can be seen in the Table 6.7 where the variances accounted for by the extracted six variables have been redistributed among them. 
Table 6.4: Initial Eigen values for variables relevant for e-Service Quality

\begin{tabular}{|l|l|l|l|}
\hline Item & Total & $\begin{array}{l}\% \\
\text { Variance }\end{array}$ & $\begin{array}{l}\text { Cumulative } \\
\%\end{array}$ \\
\hline A1 & 5.495 & 28.921 & 28.921 \\
\hline A2 & 1.8 & 9.475 & 38.397 \\
\hline A3 & 1.59 & 8.371 & 46.767 \\
\hline A4 & 1.177 & 6.193 & 52.961 \\
\hline A5 & 1.037 & 5.46 & 58.421 \\
\hline A6 & 1.006 & 5.297 & 63.718 \\
\hline A7 & 0.798 & 4.203 & 67.921 \\
\hline A8 & 0.756 & 3.977 & 71.898 \\
\hline A9 & 0.727 & 3.827 & 75.725 \\
\hline A10 & 0.625 & 3.29 & 79.015 \\
\hline A11 & 0.589 & 3.099 & 82.113 \\
\hline A12 & 0.544 & 2.862 & 84.975 \\
\hline A13 & 0.524 & 2.757 & 87.732 \\
\hline A14 & 0.48 & 2.528 & 90.26 \\
\hline A15 & 0.441 & 2.321 & 92.581 \\
\hline A16 & 0.422 & 2.219 & 94.799 \\
\hline A17 & 0.394 & 2.073 & 96.873 \\
\hline A18 & 0.34 & 1.789 & 98.662 \\
\hline A19 & 0.254 & 1.338 & 100 \\
\hline & & & \\
\hline
\end{tabular}

Table 6.5: Rotation Sums of Squared Loadings of factors as determinants of e-Service quality

\begin{tabular}{|l|l|l|l|}
\hline Factor & Total & $\begin{array}{l}\% \\
\text { Variance }\end{array}$ & $\begin{array}{l}\text { Cumulative } \\
\%\end{array}$ \\
\hline 1 & 2.912 & 15.326 & 15.326 \\
\hline 2 & 2.613 & 13.751 & 29.077 \\
\hline 3 & 2.098 & 11.04 & 40.117 \\
\hline 4 & 1.627 & 8.563 & 48.679 \\
\hline 5 & 1.511 & 7.951 & 56.631 \\
\hline 6 & 1.347 & 7.087 & 63.718 \\
\hline
\end{tabular}

Table 6.6: Rotated Component Matrix for variables relevant for e- Service Quality

\begin{tabular}{|l|l|l|l|l|l|l|l|}
\hline & \multicolumn{9}{|c|}{ Component } \\
\hline & & 1 & 2 & 3 & 4 & 5 & 6 \\
\hline & & & & & & - & - \\
A1 & Ensure security & 0.437 & 0.007 & 0.066 & $\mathbf{0 . 6 4 6}$ & 0.116 & 0.042 \\
\hline A2 & Effective grievance handling & $\mathbf{0 . 6 8 7}$ & 0.133 & 0.087 & 0.22 & 0.056 & 0.042 \\
\hline & & - & & & & & - \\
A3 & Increased comfort & 0.009 & 0.054 & $\mathbf{0 . 8 0 9}$ & 0.151 & 0.142 & 0.027 \\
\hline & & & - & & & & \\
A4 & Easy accessibility & 0.005 & 0.036 & $\mathbf{0 . 7 7 6}$ & 0.139 & 0.081 & 0.239 \\
\hline A5 & Reduced cost & 0.159 & 0.112 & 0.032 & 0.047 & 0.068 & $\mathbf{0 . 8 5 3}$ \\
\hline
\end{tabular}




\begin{tabular}{|c|c|c|c|c|c|c|c|}
\hline A6 & Easy accessibility & 0.242 & 0.111 & 0.464 & 0.028 & 0.016 & 0.599 \\
\hline A7 & Seamless transactions & 0.831 & 0.05 & 0.028 & 0.213 & 0.009 & 0.103 \\
\hline A8 & Quick response & 0.469 & 0.31 & 0.463 & 0.029 & 0.015 & 0.056 \\
\hline A9 & $\begin{array}{l}\text { Willingness of employees to } \\
\text { service customers }\end{array}$ & 0.163 & 0.709 & 0.098 & 0.029 & 0.143 & 0.103 \\
\hline A10 & Fast transactions & 0.227 & 0.441 & $\mathbf{0 . 5 7}$ & $\begin{array}{l}- \\
0.159 \\
\end{array}$ & 0.051 & - \\
\hline A11 & Ensured safety/confidentiality & 0.413 & 0.14 & 0.102 & 0.656 & 0.026 & $-\overline{0}-044$ \\
\hline A12 & Visually appealing material & 0.114 & 0.12 & 0.12 & 0.169 & 0.783 & 0.032 \\
\hline A13 & $\begin{array}{l}\text { Attractive screen layout and } \\
\text { design }\end{array}$ & 0.201 & 0.126 & 0.08 & $\begin{array}{l}- \\
0.091\end{array}$ & 0.765 & 0.033 \\
\hline A14 & Service right the first time & 0.698 & 0.096 & 0.043 & 0.065 & 0.24 & 0.161 \\
\hline A15 & $\begin{array}{l}\text { Transaction within committed } \\
\text { time }\end{array}$ & 0.651 & 0.23 & 0.039 & 0.056 & 0.217 & 0.111 \\
\hline A16 & $\begin{array}{l}\text { Employees find time to respond } \\
\text { customers }\end{array}$ & 0.151 & 0.794 & 0.099 & 0.148 & 0.032 & 0.009 \\
\hline A17 & Knowledgeable employees & 0.129 & $\mathbf{0 . 7 9 7}$ & 0.003 & 0.136 & 0.08 & 0.082 \\
\hline A18 & Instill confidence in customers & 0.004 & 0.428 & 0.088 & 0.504 & 0.284 & 0.261 \\
\hline A19 & Individual attention to customers & 0.007 & 0.459 & 0.11 & 0.524 & 0.218 & 0.239 \\
\hline
\end{tabular}

Table 6.7 : Factor Analytic (Rotated) results for e-Service Quality determinants

\begin{tabular}{|l|l|l|l|}
\hline & & Loadings & $\begin{array}{l}\text { Weighted } \\
\text { Average }\end{array}$ \\
\hline 1 & Reliability & & 3.94 \\
\hline A2 & Effective grievance handling & $\mathbf{0 . 6 8 7}$ & \\
\hline A7 & Seamless Transactions & $\mathbf{0 . 8 3 1}$ & \\
\hline A8 & Quick response & 0.469 & \\
\hline A14 & Service right the first time & $\mathbf{0 . 6 9 8}$ & \\
A15 & Transaction within committed time & $\mathbf{0 . 6 5 1}$ & \\
\hline 2 & Employee efficiency & & 3.78 \\
\hline & $\begin{array}{l}\text { Willingness of employees to service } \\
\text { customers find time to respond }\end{array}$ & 0.709 & \\
\hline A16 & $\begin{array}{l}\text { Employees } \\
\text { customers }\end{array}$ & 0.794 & \\
\hline A17 & Knowledgeable employees & $\mathbf{0 . 7 9 7}$ & \\
\hline 3 & Operational efficiency & & $\mathbf{4 . 4 7}$ \\
\hline A3 & Increased comfort & $\mathbf{0 . 8 0 9}$ & \\
\hline A4 & Easy accessibility & $\mathbf{0 . 7 7 6}$ & \\
\hline A10 & Fast transactions & $\mathbf{0 . 5 7}$ & \\
\hline 4 & Assurance & 0.646 & \\
\hline A1 & Ensure security & & \\
\hline & & & \\
\hline
\end{tabular}




\begin{tabular}{|l|l|l|l|} 
A11 & Ensured safety/confidentiality & $\mathbf{0 . 6 5 6}$ & \\
\hline A18 & Instill confidence in customers & $\mathbf{0 . 5 0 4}$ & \\
\hline & & & \\
A19 & Individual attention to customers & $\mathbf{0 . 5 2 4}$ & \\
\hline 5 & Tangible evidence/tangibles & & 3.85 \\
\hline A12 & Visually appealing material & 0.783 & \\
\hline & & & \\
A13 & Attractive screen layout and design & 0.765 & \\
\hline 6 & Value to customers & & 4.2 \\
\hline A5 & Reduced cost & 0.853 & \\
\hline A6 & Easy accessibility & 0.599 & \\
\hline
\end{tabular}

\section{Model Formulation}

The following model was used to examine the relationship between dependent variable and independent variables:

$Y=\alpha+\beta_{1} X_{1}+\beta_{2} X_{2}+\beta_{3} X_{3}+\beta_{4} X_{4}+\beta_{5} X_{5}+\beta_{6} X_{6}+\varepsilon_{i}$

Where $\mathrm{Y}=$ Dependent Variable: Overall Service Quality

$\alpha=$ Intercept

$\beta_{1}, \beta_{2}, \beta_{3}, \beta_{4}, \beta_{5}, \beta_{6}=$ Regression Coefficients

$\mathrm{X}_{1}, \mathrm{X}_{2}, \mathrm{X}_{3}, \mathrm{X}_{4}, \mathrm{X}_{5}, \mathrm{X}_{6}=$ Independent Variables

$\varepsilon_{\mathrm{i}}=$ Error Term

Table 6.8: Regression Model Summary for antecedents of e-service quality

\begin{tabular}{|c|c|c|c|c|c|}
\hline Model & $\mathrm{R}$ & $\begin{array}{l}\mathrm{R} \\
\text { Square }\end{array}$ & $\begin{array}{l}\text { Adjusted R } \\
\text { Square }\end{array}$ & $\begin{array}{l}\text { Std. } \\
\text { Error of } \\
\text { the } \\
\text { Estimate }\end{array}$ & $\begin{array}{l}\text { Durbin- } \\
\text { Watson }\end{array}$ \\
\hline 1 & 0.705 & 0.497 & 0.492 & 0.365 & 1.976 \\
\hline
\end{tabular}

The value of $\mathrm{R}^{2}$ is .497 which indicates that all the six variables together explained $49.7 \%$ variance in the dependent variable i.e. overall service quality of e-banking services. The rest $50.3 \%$ of the variance is unexplained that might be attributable to some other factors not considered in the analysis. The value of adjusted $\mathrm{R}^{2}$ tells how well the model generalizes. The model is a good fit as the difference between $\mathrm{R}^{2}$ and adjusted $\mathrm{R}^{2}$ is fairly small (.005). This indicated that the model would give $.5 \%$ variation in the outcome (prediction of overall service quality) if it were to be derived from the population rather than the sample. To check the assumption of regression analysis that the errors are independent, Durbin Watson test has been applied. The test statistic equal or closer to 2 indicates that the residuals are independent. In the present analysis, the value of Durbin Watson test outcome was found to be 1.976 which is closer to 2 . So, the data meets the assumption of independent errors.

The estimated regression equation is as follows:

$\mathrm{Y}=3.855+.137 \mathrm{X}_{1}+.20 \mathrm{X}_{2}+.131 \mathrm{X}_{3}+.166 \mathrm{X}_{4}+.139 \mathrm{X}_{5}+.086 \mathrm{X}_{6}$ 
This equation shows the predicting power of six factors in determining the overall service quality of e-banking services. All the factors have positive contribution towards predicting the value of overall service quality, together explaining $49.7 \%$ variations in the same.

\section{Conclusion}

Service quality has become a customer's requirement as well as a marketing tool, so it holds importance for both customers and business firms. Regarding e-banking services, customers' evaluation of any innovation or technological upsurge is based on improvement in service quality. So it was imperative to determine the effects of technology on various determinants or items relevant for service quality. We identified 19 variables which are influenced or expected to be influenced by technology infusion in the banking sector based on customers' experiences or expectations. These variables were summarized into six factors: 'Reliability', 'Employee efficiency', 'Operational efficiency', 'Assurance', 'Tangible evidence', and 'Value to customers', using factor analysis.

\section{References}

1. Abukhzam, M., \& Lee, A. (2010). Factors affecting bank staff attitude towards ebanking adoption in Libya. The Electronic Journal of Information Systems in Developing Countries , 42 (2), 1-15.

2. Agarwal, R., \& Karahanna, E. (2000). Time flies when you're having fun: Cognitive absorption and beliefs about information technology usage. MIS quarterly , 24 (4), 665-694.

3. Agarwal, R., \& Prasad, J. (1999). Are individual differences germane to the acceptance of new information technologies? Decision sciences , 30 (2), 361-391.

4. Ajzen, I. (1991). The theory of planned behavior. Organizational behavior and human decision processes , $50(2), 179-211$.

5. Aladwani, A. M. (2001). Online banking: a field study of drivers, development challenges, and expectations. International Journal of Information Management , 21 (3), 213-225.

6. Allred, A. T., \& Addams, H. L. (2000). Service quality at banks and credit unions: What do their customers say? Managing Service Quality , 10 (1), 52-60.

7. Ariff, M. S., Yun, L. O., Zakuan, N., \& Jusoh, A. (2012). Examining Dimensions of Electronic Service Quality for Internet Banking Services. Procedia-Social and Behavioral Sciences , 65, 854859.

8. Arora, V., Ravichandran, N., \& Jain, N. K. (2011). Dimensionality of Service Quality and Its Critical Predictors to Customer Satisfaction in Indian Retail Banking. Advances in Management, 4 (10), 1-11.

9. Avkiran, N. K. (1999). Quality customer service demands human contact. International Journal of Bank Marketing , 17 (2), 61-74.

10. Bandura, A. (1982). Self-efficacy mechanism in human agency. American psychologist , 37 (2), 122.

11. Bauer, H. H., Falk, T., \& Hammerschmidt, M. (2006). eTransQual: A transaction process-based approach for capturing service quality in online shopping. Journal of Business Research , 59 (7), 866-875.

12. Bradley, L., \& Stewart, K. (2002). A Delphi study of the drivers and inhibitors of Internet banking. International Journal of Bank Marketing , 20 (6), 250-260.

13. Buzzell, R. D. (2004). The PIMS program of strategy research: a retrospective appraisal. Journal of Business Research , 57 (5), 478-483.

14. Corrocher, N. (2002). Does Internet banking substitute traditional banking? Empirical evidence from Italy.Working Paper No. 134. CESPRI (Centro di Ricerca sui Processi di Innovazione e Internazionalizzazione) . 
15. Corrocher, N. (2006). Internet adoption in Italian banks: An empirical investigation. Research Policy, 533-544.

16. Cronin Jr, J. J., \& Taylor, S. A. (1992). Measuring service quality: A reexamination and extension. The journal of marketing , 56 (3), 55-68.

17. Dabholkar, P. A. (1995). The convergence of customer satisfaction and service quality evaluations with increasing customer patronage. Journal of consumer satisfaction,dissatisfaction and complaining behavior , 8, 32-43.

18. Dabholkar, P. A., Shepherd, C. D., \& Thorpe, D. I. (2000). A comprehensive framework for service quality: An investigation of critical conceptual and measurement issues through a longitudinal study. Journal of retailing , 76 (2), 139-173.

19. Davis, F. D. (1989). Perceived usefulness, perceived ease of use, and user acceptance of information technology. MIS quarterly, 13 (3), 319-340.

20. De Ruyter, K., Bloemer, J., \& Peeters, P. (1997). Merging service quality and service satisfaction An empirical test of an integrative model. Journal of Economic Psychology , 18 (4), 387-406.

21. Fassnacht, M., \& Koese, I. (2006). Quality of electronic services conceptualizing and testing a hierarchical model. Journal of service research , 9 (1), 19-37.

22. Fishbein, M., \& Ajzen, I. (1973). Attitudinal and normative variables as predictors of specific behavior. Journal of personality and Social Psychology , 41-57.

23. Goodhue, D. L., \& Thompson, R. L. (1995). Task-technology fit and individual performance. MIS quarterly , 19 (2), 213-236.

24. Gupta, P. K. (2008). Internet Banking in India: Consumer Concern and Bank Strategies. Global Journal of Business Research , 2 (1), 43-51.

25. Hannan, T. H., \& McDowell, J. M. (1984). The determinants of technology adoption:The case of the banking firm. The RAND Journal of Economics , 15 (3), 328-335.

26. Joshua, A. J., \& Koshy, M. P. (2009). Attitudes and Behavioural Intention Towards a Technology Based Self Service Banking Delivery Channel: The Case of ATMs. Erudition, The Albertian Journal of Management , 81-94.

27. Kesharwani, A., \& Bisht, S. S. (2012). The impact of trust and perceived risk on internet banking adoption in India: An extension of technology acceptance model. International Journal of Bank Marketing , 30 (4), 303-322.

28. Khan, M. S., Mahapatra, S. S., \& Sreekumar. (2009). Service quality evaluation in internet banking: An empirical study in India. International Journal of Indian Culture and Business Management , 2 (1), 30-46.

29. Kumra, R., \& Mittal, R. K. (2004). Growth Drivers of IT Enabled Banking in India:A Study of Scheduled Commercial Banks. LBS Journal of Management \& Research , 2 (1), 60-72.

30. Malhotra, P., \& Singh, B. (2007). Determinants of Internet banking adoption by banks in India. Internet Research , 17 (3), 323-339.

31. Mansor, N., \& Mat, A. C. (2009). Islamic credit card: Are demographic factors a good indicator? Asian Social Science , 5 (12), 17-26.

32. Margaret, M., \& Ngoma, M. F. (2013). Socio-demographic factors influencing adoption of Internet banking in Zimbabwe. Journal of Sustainable Development in Africa , 15 (8), 145-154.

33. Naik, C. K., Gantasala, S. B., \& Prabhakar, G. B. (2010). Service quality (Servqual) and its effect on customer satisfaction in retailing. European Journal of Social Sciences , 16 (2), 231-243.

34. Oliver, R. L. (1989). Processing of the satisfaction response in consumption: a suggested framework and research propositions. Journal of Consumer Satisfaction Dissatisfaction and Complaining Behavior , 2 (1), 1-16. 
35. Parasuraman, A., \& Zeithaml, V. A. (2005). ES-QUAL a multiple-item scale for assessing electronic service quality. Journal of service research , 7 (3), 213-233.

36. Parasuraman, A., Zeithaml, V. A., \& Berry, L. L. (1988). Servqual. Journal of retailing , 64 (1), $12-40$.

37. Pennings, J. M., \& Harianto, F. (1992). The diffusion of technological innovation in the commercial banking industry. Strategic Management Journal , 29-46.

38. Phillips, L. W., Chang, D. R., \& Buzzell, R. D. (1983). Product quality, cost position and business performance: A test of some key hypotheses. The Journal of Marketing , 47 (3), 26-43.

39. Purohit, H. C., \& Pathardikar, A. D. (2007). Service Quality Measurement and Consumer Perception about the Services of Banking Institutions. Indian Journal of Marketing , 37 (3), 12-18.

40. Rogers, E. M. (2003). Diffusion of innovations. Free Press, New York .

41. Sharma, H. (2011). Banker's Perspective on e-banking. NJRIM , 1, 71-84.

42. Sohail, M. S., \& Shaikh, N. M. (2008). Internet banking and quality of service:Perspectives from a developing nation in the Middle East. Online Information Review , 32 (1), 58-72.

43. Spreng, R. A., \& Mackoy, R. D. (1996). An empirical examination of a model of perceived service quality and satisfaction. Journal of retailing , 72 (2), 201-214.

44. Sudhahar, J. C., Israel, D., \& Selvam, M. (2006). Service quality measurement in Indian retail banking sector: CA approach. Journal of applied Sciences , 6, 2377-2385.

45. Sureshchandar, G. S., Rajendran, C., \& Anantharaman, R. N. (2002). Determinants of customerperceived service quality: A confirmatory factor analysis approach. Journal of Services Marketing , $16(1), 9-34$.

46. Vaithilingam, S., Nair, M., \& Samudram, M. (2006). Key drivers for soundness of the banking sector: lessons for developing countries. Journal of Global Business \& Technology , 2 (1), 1-11.

47. Venkatesh, V., \& Davis, F. D. (1996). A model of the antecedents of perceived ease of use: Development and test. Decision sciences , 27 (3), 451-481.

48. Venkatesh, V., \& Morris, M. G. (2000). Why don't men ever stop to ask for directions? Gender, social influence, and their role in technology acceptance and usage behavior. MIS quarterly , 24 (3), 115-139.

49. Venkatesh, V., Morris, M. G., Davis, G. B., \& Davis, F. D. (2003). User acceptance of information technology: Toward a unified view. MIS quarterly , 27 (3), 425-478.

50. Wang, I. M., \& Shieh, C. J. (2006). The relationship between service quality and customer satisfaction: the example of CJCU library. Journal of Information and Optimization Sciences , 27 (1), 193-209.

51. Wong, D. H., Rexha, N., \& Phau, I. (2008). Re-examining traditional service quality in an ebanking era. International Journal of Bank Marketing , 26 (7), 526-545.

52. Zeithaml, V. A., Berry, L. L., \& Parasuraman, A. (1988). Communication and control processes in the delivery of service quality. The Journal of Marketing , 52 (2), 35-48. 